\title{
Pertumbuhan dan Hasil Tanaman Pakchoy Pada Tanah Berpasir Dengan Pemberian Biochar dan Pupuk Kandang Sapi
}

\section{Growth and Yield of Pakchoy on Sandy Soil by Using Biochar and Cow Manure Fertilizer}

\author{
Eva Aprilia Saesarini Pangaribuan*, Adriani Darmawati, Susilo Budiyanto \\ Department of Agroecotechnology, Faculty of Animal and Agricultural Science, Universitas Diponegoro, Semarang, Indonesia \\ ${ }^{*}$ Corresponding author: adrianidarmawati@gmail.com
}

Received: June 10, 2020; Accepted: August 18, 2020; Published: October 1, 2020

\begin{abstract}
Sandy soil is very difficult to remain the water and nutrients so that leaching often occurs before nutrients absorbed by the roots. It can be happen because sandy soil has many macro pores in the soil. This research was aimed to study the effect of biochar and cow manure fertilizer for growth and products of Brassica rapa L. plants on sandy soil. The method used was factorial completely randomized design with 2 factors. This first factor was type of biochar (paddy husk biochar and corn cobs biochar) and the second factor was dosage of cow manure fertilizer ( 5 tons/ha, 10 tons/ha, 15 tons/ha, 20 tons/ha, 25 tons/ha). The result showed that the application of cow manure fertilizer had significant effected on bulk density and soil porosity. The interaction between the type of biochar and dosage of cow manure fertilizer had significant effect on ground water content. The application of biochar and high doses of cow manure fertilizer resulted in increased ground water content on sandy soil. The type of biochar and dosage of cow manure fertilizer had no significant effect on the nitrogen uptake, plant height, number of leaves, and crown fresh weight.
\end{abstract}

Key words: bulk density, porosity, water content

Cite this as: Pangaribuan, E. A. S., Darmawati, A., \& Budiyanto, S. (2020). Pertumbuhan dan Hasil Tanaman Pakchoy Pada Tanah Berpasir Dengan Pemberian Biochar dan Pupuk Kandang Sapi. Agrosains : Jurnal Penelitian Agronomi 22(2): 72-78. DOI: http://dx.doi.org/10.20961/agsjpa.v22i2.42093

\section{PENDAHULUAN}

Tanah berpasir memiliki banyak pori makro sehingga kemampuan untuk menahan air di dalam tanah sangat sulit (Dokoohaki et al., 2017). Kondisi tersebut sering menyebabkan terjadinya penguapan sebelum tanaman menyerap air dari dalam tanah sedangkan air berperan besar terhadap pertumbuhan dan perkembangan suatu tanaman khususnya dalam melakukan proses fotosintesis. Perbaikan sifat fisika, kimia, dan biologi tanah dapat dilakukan dengan pemberian bahan organik. Kandungan C-organik dan pori-pori mikro tanah dapat ditingkatkan dengan pemberian bahan organik ke tanah. Pori mikro tanah berperan sebagai pengikat air (Carvalho et al., 2020).

Bahan organik yang dapat dijadikan sebagai bahan pembenah tanah (amelioran) adalah biochar dan pupuk kandang. Penambahan biochar pada lapisan tanah dapat memperbaiki struktur tanah, menambah karbon organik, mempertinggi daya serap dan jerap air, serta dapat memperbaiki pertumbuhan tanaman. Penambahan pupuk kandang bertujuan untuk meningkatkan agregasi tanah, peningkatan C-organik yang berpengaruh terhadap mikro organisme tanah, menurunkan tingkat kepadatan tanah, dan meningkatkan porositas tanah. Peningkatan porositas tanah menunjukkan terdapat perbaikan pori mikro tanah sehingga terjadi peningkatan air tersedia (Wibowo et al., 2016). Tingkat mengikat air yang rendah mengakibatkan unsur hara yang diperlukan tanaman tercuci dengan cepat. Biochar memiliki simbiosis yang baik dengan pupuk kandang, seperti peningkatan karbon di dalam tanah, peningkatan unsur hara melalui fiksasi nitrogen mikroba, dan peningkatan unsur hara yang berasal dari biochar dan pupuk kandang itu sendiri. Aplikasi biochar harus dimodifikasi dengan penambahan unsur hara agar tanaman dapat tumbuh dan berproduksi lebih optimal karena adanya peningkatan unsur hara (Hasibuan, 2017) dan berperan dalam perbaikan sifat fisik tanah khususnya kapasitas dalam mengikat air (Herath et al., 2013).

Perbaikan kualitas tanah karena aplikasi bahan organik harus berdampak terhadap peningkatan produktivitas tanaman. Sayuran adalah salah satu komponen makanan sehat sehingga permintaan semakin meningkat seiring dengan kesadaran masyarakat tentang kesehatan tubuh. Pakchoy atau dengan nama umum sawi merupakan sayuran hijau yang diminati masyarakat. Produksi tanaman sawi di Indonesia tahun 2018 sebesar 635,982 ton/ha dengan luas panen 61,047 ha sedangkan tahun 2019 sebesar 652,723 ton/ha dengan luas panen 60.871 ha (Direktorat Jendral Hortikultura, 2020). Budidaya yang baik akan menghasilkan hasil panen pakchoy yang tinggi dan berkualitas. Tanaman pakchoy akan tumbuh baik jika dibudidayakan di lahan gembur dan kandungan unsur haranya mencukupi namun dapat juga tumbuh di tanah 
berpasir dengan penambahan pupuk organik (Zupriadi et al., 2018). Bahan organik akan melepaskan nitrogen dan senyawa lain sehingga unsur hara yang diserap dan hasil fotosintesis akan optimal (Augustien dan Suhardjono, 2017). Keunggulan lain dari penggunaan bahan organik adalah dapat memperbaiki sifat fisik tanah sehingga penyerapan unsur hara dan air oleh akar semakin optimal. Bahan organik yang telah terurai akan meningkatkan ketersediaan $\mathrm{N}$ di dalam tanah karena mengalami proses mineralisasi sehingga nitrogen lebih banyak tersedia di tanah (Suharyani et al., 2012). Unsur nitrogen sangat penting dalam proses fotosintesis sehingga semakin tinggi unsur yang terkandung maka banyak jumlah daun fotosintat yang dihasilkan. Unsur nitrogen juga membantu dalam proses metabolisme tanaman.

Biochar hanya mengandung sedikit unsur hara khususnya nitrogen sehingga harus dimodifikasi dengan mencampurkan unsur hara lain agar tanaman dapat tumbuh dan memiliki hasil produksi yang optimal (Hasibuan, 2017). Kombinasi biochar dan pupuk kandang sapi dapat meningkatkan $\mathrm{pH}$ dan KTK (Kapasitas Tukar Kation) tanah (Wibowo et al., 2016) yang menyebabkan unsur hara lebih tersedia sehingga pertumbuhan tanaman semakin baik dan penyerapan unsur hara serta air oleh akar tanaman tidak terganggu. Aplikasi biochar dan pupuk kandang sapi diharapkan dapat menjadi alternatif perbaikan tanah sehingga menghasilkan tanaman pakchoy yang berkualitas. Tujuan penelitian yaitu mengkaji pengaruh aplikasi jenis biochar dan pupuk kandang sapi serta interaksi antara dua jenis perlakuan terhadap pertumbuhan dan hasil tanaman pakchoy di tanah berpasir.

\section{BAHAN DAN METODE}

Penelitian telah dilaksanakan di Greenhouse dan dilanjutkan dengan analisis laboratorium di Laboratorium Ekologi dan Produksi Tanaman, Departemen Pertanian, Fakultas Peternakan dan Pertanian, Universitas Diponegoro, Semarang, Jawa Tengah pada Desember 2019 - Februari 2020. Lokasi penelitian secara geografis

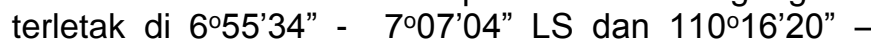
110'30'29" BT dengan ketinggian tempat 125 meter di atas permukaan laut. Bahan yang digunakan dalam penelitian ini diantaranya adalah benih pakchoy varietas Nauli F1, biochar (sekam padi dan tongkol jagung) dan pupuk kandang sapi. Alat yang digunakan dalam penelitian adalah ring sample, piknometer dan oven. Percobaan menggunakan Rancangan Acak Lengkap (RAL) pola faktorial $2 \times 5$ dengan 3 ulangan sehingga terdapat 30 unit percobaan. Faktor pertama adalah perlakuan jenis biochar yang terdiri atas 2 perlakuan, yaitu biochar sekam padi 5 ton/ha $\left(\mathrm{T}_{1}\right)$ dan biochar tongkol jagung 5 ton/ha $\left(\mathrm{T}_{2}\right)$. Faktor kedua adalah perlakuan dosis pupuk kandang sapi yang terdiri atas 5 tingkat, yaitu 5 ton/ha $\left(D_{1}\right), 10$ ton/ha $\left(D_{2}\right), 15$ ton/ha $\left(D_{3}\right)$, 20 ton/ha $\left(D_{4}\right)$, dan 25 ton/ha $\left(D_{5}\right)$.

Penelitian dilaksanakan dengan beberapa tahap yaitu persiapan, pemberian perlakuan, penanaman, pemeliharaan tanaman, pengamatan rutin, dan panen. Tahap persiapan meliputi penyiapan media tanam tanah yaitu tanah berpasir dengan memasukkan tanah seberat $4 \mathrm{~kg}$ ke dalam masing - masing polibag. Tanah yang digunakan pada penelitian adalah tanah dengan tekstur lempung berpasir yang diambil dari Dusun Ponggok, Sidomulyo, Kecamatan Bambanglipuro, Kabupaten
Bantul, Yogyakarta. Tahap perlakuan, polibag yang sudah berisi dengan media tanam, diberikan biochar (sekam padi dan tongkol jagung), serta pupuk kandang sapi dengan kombinasi sesuai rancangan percobaan yang sudah ditentukan. Kandungan tanah berpasir sebelum tanam, biochar (sekam padi dan tongkol jagung), dan pupuk kandang sapi dapat dilihat pada Tabel 1. Media tanam yang telah diberi perlakuan didiamkan selama 1 minggu dengan menjaga kapasitas lapang tanah. Tahap penanaman, benih pakchoy yang telah disemai dan berumur 2 minggu dipindahkan ke polibag yang sudah diberi perlakuan. Tahap pemeliharaan dilakuan dengan disiram pada pagi dan sore hari dan Organisme Pengganggu Tanaman (OPT) pada tanaman pakchoy dikendalikan manual dan menggunakan pestisida organik berbahan aktif azadirachtin. Tahap pengamatan yaitu setelah pindah tanam diambil data sesuai parameter. Pemanenan tanaman pakchoy varietas Nauli F1 dilakukan pada umur tanaman 7 MSS (minggu setelah semai). Parameter pengamatan meliputi berat volume, porositas, kadar air tanah, serapan nitrogen, tinggi tanaman, jumlah daun, dan berat segar tajuk. Data yang diperoleh dianalisis ragam (Uji F) untuk mengetahui pengaruh perlakuan dan jika ada pengaruh nyata akan dilanjutkan uji jarak berganda Duncan (Duncan's Multiple Range Test) pada taraf 5\% dan Polinomial Ortogonal (PO).

Tabel 1. Analisis tanah sebelum tanam, biochar, dan pupuk kandang sapi

\begin{tabular}{lllll} 
Karakteristik & Tanah & $\begin{array}{l}\text { Biochar } \\
\text { Sekam } \\
\text { Padi }\end{array}$ & $\begin{array}{l}\text { Biochar } \\
\text { Tongkol } \\
\text { Jagung }\end{array}$ & $\begin{array}{l}\text { Pupuk } \\
\text { Kandang } \\
\text { Sapi }\end{array}$ \\
\hline $\mathrm{pH}$ & 6,45 & 7,05 & 10,25 & 7,79 \\
C-Organik (\%) & 0,62 & & & \\
$\mathrm{~N}$ Total (\%) & 0,05 & 0,50 & 0,59 & 1,80 \\
$\mathrm{P}_{2} \mathrm{O}$ (\%) & & 0,97 & 1,16 & 0,71 \\
$\mathrm{~K} 2 \mathrm{O}(\%)$ & & 1,78 & 4,53 & 1,50 \\
$\mathrm{C} / \mathrm{N}$ & & 74,24 & 84,46 & 21,63 \\
Pasir & 67,73 & & & \\
Debu & 21,69 & & & \\
Liat & 10,98 & & & \\
\hline
\end{tabular}

\section{HASIL DAN PEMBAHASAN \\ Berat Volume Tanah}

Hasil analisis ragam menunjukkan bahwa tidak ada interaksi antara pemberian jenis biochar dan dosis pupuk kandang sapi terhadap berat volume tanah. Pemberian jenis biochar tidak menunjukkan pengaruh terhadap berat volume tanah. Pemberian dosis pupuk kandang sapi berpengaruh terhadap berat volume tanah. Berat volume tanah pada berbagai dosis pupuk kandang sapi dapat dilihat pada Tabel 2. Hasil penelitian menunjukkan bahwa berat volume tanah lempung berpasir yang diberi pupuk kandang sapi 5 ton/ha (D1) lebih rendah dibandingkan dengan yang diberi pupuk kandang 10 ton/ha (D2), 20 ton/ha (D4), dan 25 ton/ha (D5), namun sama dengan pemberian pupuk kandang sapi 15 ton/ha (D3). Hal ini dapat menunjukkan bahwa pemberian pupuk kandang sapi akan mempengaruhi nilai berat volume tanah.

Perlakuan aplikasi pupuk kandang sapi berpengaruh nyata dibanding dengan biochar dikarenakan dalam biochar banyak terkandung lignin dibandingkan dengan pupuk kandang sapi sehingga membutuhkan waktu panjang untuk bereaksi dengan tanah. Didukung dengan pendapat Aslam et al., (2014) bahwa biochar memiliki 
struktur aromatik sehingga membutuhkan jangka waktu yang lama untuk terdekomposisi. Berdasarkan uji polinomial ortogonal, menunjukkan bahwa berat volume tanah mempunyai pola kecenderungan meningkat seiring bertambahnya tingkat dosis pupuk kandang sapi yang diberikan dengan mengikuti pola linier (Gambar 1).

Persamaan linier hubungan antara berat volume tanah dengan dosis pupuk kandang sapi adalah $\mathrm{Y}=$ $0,01 X+1,10$ dengan $R 2=0,63$ ini menunjukkan bahwa berat volume tanah $63 \%$ ditentukan oleh pupuk kandang sapi, di mana $X$ adalah dosis pupuk kandang sapi dan $Y$ adalah berat volume tanah. Hubungan tersebut menunjukkan kecenderungan positif yaitu dosis pupuk kandang yang meningkat berbanding lurus dengan berat volume tanah. Kondisi tersebut diduga karena $\mathrm{C} / \mathrm{N}$ rasio dari pupuk kandang sapi yang tergolong agak tinggi yaitu
$21,63 \%$.

Faktor yang mengakibatkan peningkatan dosis pupuk kandang sapi yang belum terurai berkolerasi positif dengan peningkatan berat volume diduga karena pupuk kandang sapi yang belum terurai masih memiliki massa yang tergolong berat sehingga peningkatan dosis pupuk akan membuat tanah menjadi mampat. Kandungan bahan organik pada pupuk kandang sapi masih berupa butir - butir padat yang sulit terdekomposisi. Butiran padat tersebut akan menambah massa padatan pada tanah karena akan menambah gaya tekan pada permukaan tanah sehingga ruang total pori menjadi sempit. Sesuai pendapat Yuan et al., (2018) bahwa semakin besar massa padatan suatu jenis tanah maka besar pula nilai berat volume serta semakin rendah total ruang pori tanah.

Tabel 2. Berat volume tanah akibat aplikasi jenis biochar dan pupuk kandang sapi

\begin{tabular}{ccccccc}
\hline \multirow{2}{*}{ Jenis Biochar } & \multicolumn{4}{c}{ Dosis Pupuk Kandang Sapi } & \multirow{2}{*}{ Rata - rata } \\
\cline { 2 - 5 } & $\mathrm{D}_{1}$ & $\mathrm{D}_{2}$ & $\mathrm{D}_{3}$ & $\mathrm{D}_{4}$ & $\mathrm{D}_{5}$ & 1,24 \\
$\mathrm{~T}_{1}$ & 1,12 & 1,24 & 1,25 & 1,27 & 1,34 & 1,21 \\
$\mathrm{~T}_{2}$ & 1,12 & 1,21 & 1,11 & 1,34 & 1,27 & 1,23 \\
Rata - rata & $1,12^{\mathrm{c}}$ & $1,22^{\mathrm{ab}}$ & $1,18^{\mathrm{bc}}$ & $1,30^{\mathrm{a}}$ & $1,30^{\mathrm{a}}$ & \\
\hline
\end{tabular}

Keterangan: Superskrip yang berbeda pada baris yang sama menunjukkan berbeda nyata $(p<0,05)$

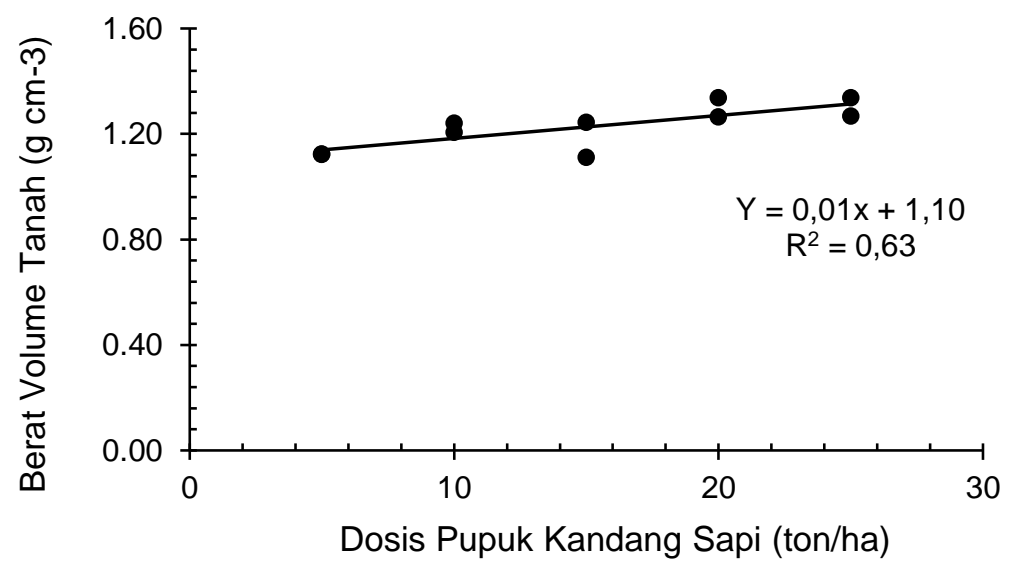

Gambar 1. Berat volume tanah tekstur lempung berpasir dengan berbagai dosis pupuk kandang sapi

Bahan organik yang sudah terurai berperan membentuk agregat tanah yang stabil sehingga dapat merubah berat volume serta porositas tanah menjadi lebih baik. Berat volume menunjukkan nilai kepadatan tanah yang dipengaruhi bahan organik dan tekstur tanah. Semakin tinggi berat volume maka semakin padat tanah sehingga akar tanaman akan mengalami kesulitan untuk menembus masuk ke dalam tanah yang lebih dalam. Kasih et al., (2019) menjelaskan bahwa semakin tinggi bulk density maka tanah akan semakin padat sehingga sulit untuk ditembus oleh akar.

\section{Porositas Tanah}

Hasil analisis ragam menunjukkan bahwa tidak ada interaksi antara pemberian jenis biochar dan dosis pupuk kandang sapi terhadap porositas tanah. Pemberian jenis biochar tidak menunjukkan pengaruh terhadap porositas tanah. Pemberian dosis pupuk kandang sapi berpengaruh terhadap porositas tanah. Porositas tanah pada berbagai dosis pupuk kandang sapi dapat dilihat pada Tabel 3. Hasil penelitian menunjukkan porositas tanah pada pemberian dosis pupuk kandang sapi 5 ton/ha $\left(D_{1}\right)$ sama bila dibandingkan dengan dosis 15 ton/ha $\left(D_{3}\right)$, namun lebih tinggi bila dibandingkan dengan dosis 10 ton/ha $\left(D_{2}\right), 20$ ton/ha $\left(D_{4}\right)$, dan 25 ton/ha ( $\left.D_{5}\right)$. Hal ini menunjukkan pupuk kandang sapi yang diberikan akan mempengaruhi porositas.Berdasarkan uji polinomial ortogonal, menunjukkan bahwa porositas tanah mempunyai pola kecenderungan menurun seiring bertambahnya tingkat dosis pupuk kandang sapi yang diberikan dengan mengikuti pola linier (Gambar 2).

Tabel 3. Porositas tanah akibat aplikasi pemberian jenis biochar dan pupuk kandang sapi

\begin{tabular}{ccccccc}
\hline \multirow{2}{*}{ Jenis Biochar } & \multicolumn{4}{c}{ Dosis Pupuk Kandang Sapi (ton/ha) } & \multirow{2}{*}{ Rata - rata } \\
\cline { 2 - 6 } & $\mathrm{D}_{1}$ & $\mathrm{D}_{2}$ & $\mathrm{D}_{3}$ & $\mathrm{D}_{4}$ & $\mathrm{D}_{5}$ & 0,48 \\
$\mathrm{~T}_{1}$ & 0,55 & 0,48 & 0,48 & 0,47 & 0,44 & 0,49 \\
$\mathrm{~T}_{2}$ & 0,54 & 0,48 & 0,52 & 0,44 & 0,46 & 0,48 \\
Rata - rata & $0,54^{\mathrm{a}}$ & $0,48^{\mathrm{bc}}$ & $0,50^{\mathrm{ab}}$ & $0,45^{\mathrm{c}}$ & $0,45^{\mathrm{c}}$ & 0,49 \\
\hline
\end{tabular}

Keterangan: Superskrip yang berbeda pada baris yang sama menunjukkan berbeda nyata $(p<0,05)$ 


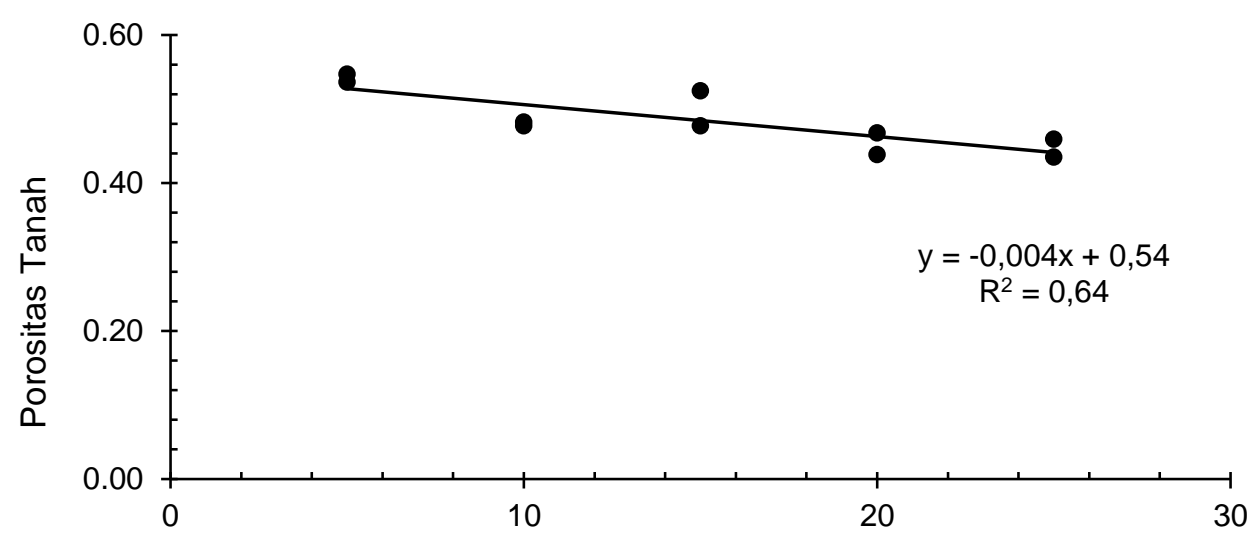

Dosis Pupuk Kandang Sapi (ton/ha)

Gambar 2. Porositas tanah tekstur lempung berpasir dengan berbagai dosis pupuk kandang sapi

Persamaan linier hubungan antara porositas tanah dengan dosis pupuk kandang sapi adalah $\mathrm{Y}=-0,004 \mathrm{X}+$ 0,54 dengan $R^{2}=0,64$ ini menunjukkan bahwa berat volume tanah $64 \%$ ditentukan oleh pupuk kandang sapi, di mana $X$ adalah dosis pupuk kandang sapi dan $Y$ adalah porositas tanah. Hubungan tersebut menunjukkan kecenderungan negatif yaitu porositas akan menurun ketika pupuk kandang sapi yang diberi itu besar. Nilai porositas tanah akan selalu berbanding terbalik dengan nilai berat volume tanah. Porositas merupakan bagian yang terisi oleh air dan udara. Menurut pendapat Indoria et al., (2017) nilai kepadatan tanah yang tinggi mengakibatkan nilai porositas tanah akan berkurang, tingkat pergerakan air dan udara terbatas sehingga menghambat penetrasi akar tanaman. Menurunnya porositas tanah disebabkan adanya peningkatan kepadatan tanah yang mengakibatkan ruang pori dalam tanah menjadi sedikit. Umumnya tanah yang mengalami pemadatan memiliki pori - pori mikro lebih banyak dibanding dengan pori - pori makro. Pupuk kandang sapi yang diberikan belum sempurna dalam proses dekomposisi dikarenakan waktu percobaan yang singkat sehingga belum mampu menciptakan kondisi yang sesuai bagi mikro organisme tanah untuk membentuk pori - pori dalam tanah yang dapat meningkatkan porositas. Menurut pendapat Marzuki et al., (2012) humus hasil penguraian bahan organik berperan dalam menyediakan unsur hara, penurunan kepadatan tanah, dan porositas.

\section{Kadar Air Tanah}

Hasil analisis ragam menunjukkan bahwa terdapat interaksi antara pemberian jenis biochar dan dosis pupuk kandang sapi terhadap kadar air tanah. Pemberian jenis biochar tidak menunjukkan pengaruh terhadap kadar air tanah. Pemberian dosis pupuk kandang sapi tidak menunjukkan pengaruh terhadap kadar air tanah. Kadar air tanah akibat perlakuan jenis biochar dan pupuk kandang sapi berdasarkan hasil uji jarak berganda Duncan $(p<0,05)$ dapat dilihat pada Tabel 4. Hasil penelitian menunjukkan pada pemberian biochar sekam padi $\left(\mathrm{T}_{1}\right)$ perlakuan dosis pupuk kandang sapi tidak menunjukkan perbedaan terhadap kadar air tanah. Kadar air tanah pada perlakuam biochar tongkol jagung $\left(T_{2}\right)$ yang diberi pupuk kendang sapi dosis 5 ton/ha $\left(D_{1}\right)$ sama dengan dosis 15 ton/ha $\left(D_{3}\right), 20$ ton/ha $\left(D_{4}\right)$, dan 25 ton/ha $\left(D_{5}\right)$ tetapi lebih rendah dari dosis pupuk kandang sapi 10 ton/ha $\left(D_{2}\right)$. Kadar air pada perlakuan biochar tongkol jagung dengan dosis pupuk kandang sapi 10 ton/ha lebih tinggi dibandingkan dosis 15 ton/ha tetapi sama dengan dosis 20 ton/ha dan 25 ton/ha. Hal ini menunjukkan bahwa kombinasi biochar dan pupuk kandang sapi akan mempengaruhi kadar air tanah. Berdasarkan uji polinomial ortogonal, menunjukkan bahwa kadar air tanah mempunyai pola kecenderungan dengan mengikuti pola linier (Gambar 3).

Persamaan linier hubungan antara kadar air tanah dengan dengan dosis pupuk kandang sapi untuk biochar sekam padi adalah $Y=0,12 X+20,6\left(R^{2}=0,1\right)$, sedangkan untuk biochar tongkol jagung adalah $\mathrm{Y}=$ $0,12 X+20,8\left(R^{2}=0,5\right)$, di mana $X$ adalah dosis pupuk kandang sapi dan $\mathrm{Y}$ adalah kadar air tanah. Hubungan tersebut menunjukkan kecenderungan positif yaitu kadar air meningkat saat pupuk kandang sapi diberikan dengan dosis tinggi. Hal ini membuktikan bahwa biochar dan pupuk kandang sapi bekerja secara sinergis untuk meningkatkan daya simpan air di tanah. Kombinasi pupuk kandang sapi 25 ton/ha dengan biochar tongkol jagung menghasilkan kadar air tertinggi dibanding dengan perlakuan biochar sekam padi, hal tersebut dapat terjadi karena biochar tongkol jagung memiliki kandungan karbon lebih banyak dibanding biochar sekam padi. Dariah dan Nurida (2012) menambahkan bahwa semakin besar bahan organik maka meningkatkan kemampuan memagang air.

Tanah yang memiliki jumlah partikel kasar dibandingkan partikel halus lebih banyak, akan berpengaruh terhadap meningkatnya jumlah pori - pori makro. Pemberian biochar merupakan alternatif yang tepat dalam meningkatkan jumlah pori mikro karena memiliki pori - pori yang halus dan bersifat porous yaitu memiliki pori dalam jumlah banyak sehingga kemampuan tanah untuk menyerap air tinggi. Pemberian pupuk kandang sapi akan meningkatkan daya mengikat air karena pori makro menurun sedangkan pori mikro meningkat. C-organik yang berada di bahan amelioran dapat meningkatkan kadar air pada tanah. Hal ini sesuai pendapat Damayani et al., (2014) yang menyatakan hasil akhir proses dekomposisi bahan organik akan membuat kadar air dalam tanah tinggi karena luas permukaan dan tingkat adsorbsi yang dimiliki lebih besar dibanding liat maka aplikasi bahan organik ke tanah berbanding lurus dengan kadar air. 
Tabel 4. Kadar air tanah akibat aplikasi jenis biochar dan pupuk kandang sapi

\begin{tabular}{|c|c|c|c|c|c|c|}
\hline \multirow[b]{2}{*}{ Jenis Biochar } & \multicolumn{5}{|c|}{ Dosis Pupuk Kandang Sapi } & \multirow[b]{2}{*}{ Rata - rata } \\
\hline & $\mathrm{D}_{1}$ & $\mathrm{D}_{2}$ & $\mathrm{D}_{3}$ & $\mathrm{D}_{4}$ & $\mathrm{D}_{5}$ & \\
\hline & & $21 \mathrm{bc}$ & & & 0 a & \\
\hline 1 & $21^{100}$ & $21^{00}$ & $24^{\text {aw }}$ & $23^{\text {auc }}$ & $23^{2 a c c}$ & 22 \\
\hline $\mathrm{T}_{2}$ & $20^{\mathrm{DC}}$ & $26^{a}$ & $19^{c}$ & $24^{\mathrm{ab}}$ & $24^{\mathrm{ab}}$ & 23 \\
\hline Rata - rata & 20 & 24 & 21 & 24 & 23 & 22 \\
\hline
\end{tabular}

Keterangan: Superskrip yang berbeda pada matriks interaksi menunjukkan berbeda nyata $(p<0,05)$

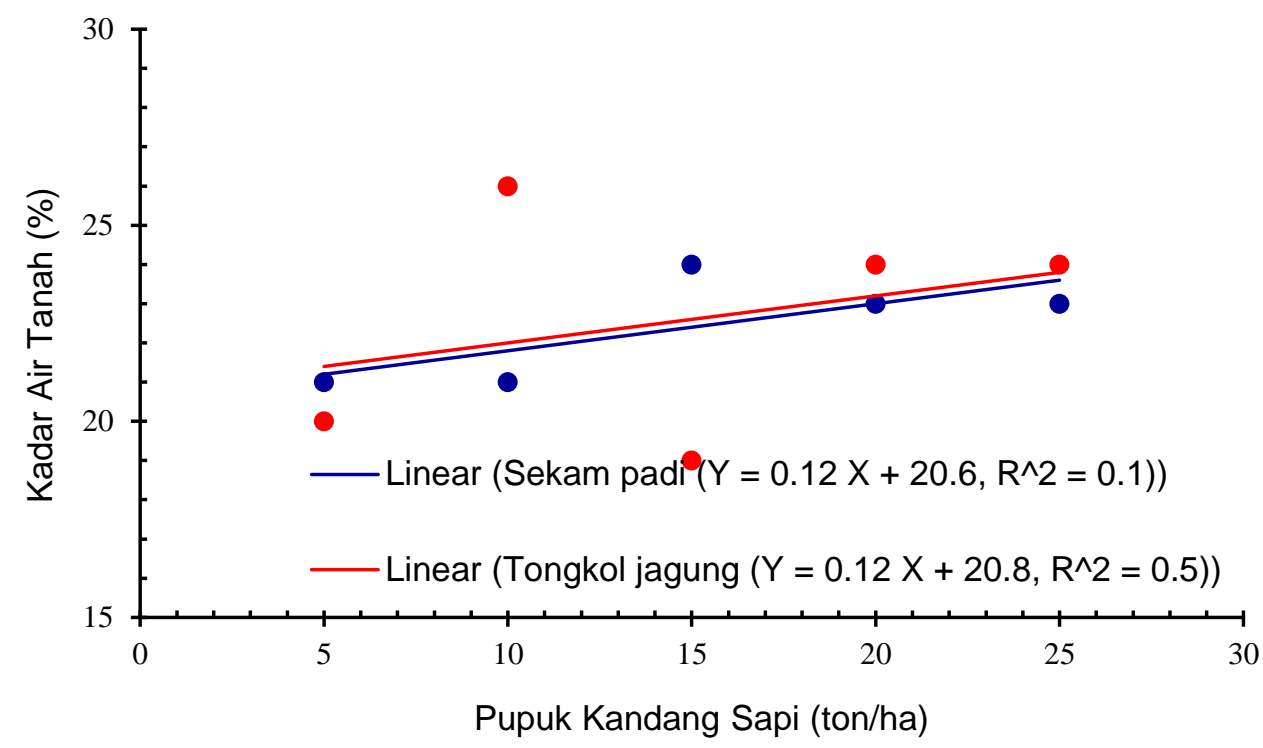

Gambar 3. Kadar air tanah tekstur lempung berpasir dengan kombinasi biochar dan pupuk kandang sapi

\section{Serapan Nitrogen}

Hasil analisis ragam menunjukkan bahwa tidak terdapat interaksi antara pemberian jenis biochar dan dosis pupuk kandang sapi terhadap serapan nitrogen tanaman pakchoy. Pemberian jenis biochar tidak menunjukkan pengaruh terhadap serapan nitrogen. Pemberian dosis pupuk kandang sapi tidak menunjukkan pengaruh terhadap serapan nitrogen. Serapan nitrogen akibat perlakuan biochar dan pupuk kandang sapi disajikan pada Tabel 5 . Tabel 5 menunjukkan bahwa tanaman pakchoy yang diberi perlakuan jenis biochar, dosis pupuk kandang sapi, dan kombinasi kedua perlakuan tidak berpengaruh nyata terhadap serapan nitrogen. Hal ini diduga kadar nitrogen yang diserap oleh akar tanaman relatif sama untuk setiap perlakuan. Cepat lambatnya unsur hara diserap oleh tanaman dipengaruhi dengan lamanya proses penguraian dari setiap perlakuan. Sifat fisik tanah akan mempengaruhi daya serap unsur hara oleh akar akan tetapi pupuk kandang sapi yang digunakan dalam penelitian ini belum selesai dalam proses penguraian sehingga belum terjadi perbaikan struktur dan porositas tanah lempung berpasir secara keseluruhan yang dapat meningkatkan hasil. Hal tersebut menyebabkan akar terhambat untuk menyerap nutrisi dari tanah. Hal ini sesuai pendapat Marlina et al., (2015) bahwa tumbuh dan berkembangnya tanaman akan terganggu jika perkembangan akar juga terhambat sehingga unsur hara makro yang diserap tergolong rendah.

Struktur tanah yang kurang baik mempengaruhi pertumbuhan dan hasil tanaman melalui perkembangan dan proses fisiologi akar tanaman seperti absorpsi unsur hara, absorpsi air, dan pertukaran udara. Hal ini didukung oleh pendapat Binardi (2014) bahwa struktur tanah yang gembur membuat akar dalam menyerap unsur hara sekam padi dan tongkol jagung dalam hal ini juga belum efektif pemanfaatannya karena dekomposisinya sangat lambat dibandingkan pupuk kandang sapi sehingga hara yang dibutuhkan dan tersedia bagi tanaman sangat sedikit. Biochar mengandung beberapa unsur hara esensial namun walaupun begitu biochar hanya dapat memberikan sedikit tambahan unsur hara. Indikator mencapai kualitas panen yang baik dapat dilihat dari serapan nitrogen tanaman. Fase pertumbuhan dan perkembangan akan berjalan secara optimal ketika akar dapat menyerap optimal nutrisi dalam tanah. Serapan nitrogen yang tinggi berkorelasi positif dengan meningkatnya proses fotosintesis. Hal ini didukung oleh Sholikhin et al., (2014) bahwa ketika serapan nitrogen tinggi maka klorofil juga tinggi sehingga hasil fotosintat dan yang didistribusikan ke bagian tanaman juga besar.

Tabel 5. Serapan nitrogen tanaman pakchoy akibat perlakuan jenis biochar dan pupuk kandang sapi

\begin{tabular}{ccccccc}
\hline Jenis & \multicolumn{4}{c}{ Dosis Pupuk Kandang Sapi } & Rata \\
\cline { 2 - 5 } Biochar & $\mathrm{D}_{1}$ & $\mathrm{D}_{2}$ & $\mathrm{D}_{3}$ & $\mathrm{D}_{4}$ & $\mathrm{D}_{5}$ & - rata \\
\hline $\mathrm{T}_{1}$ & 0,94 & 0,69 & 0,89 & 0,66 & 0,57 & 0,75 \\
$\mathrm{~T}_{2}$ & 0,70 & 0,53 & 0,76 & 0,45 & 0,85 & 0,66 \\
Rata - & 0,82 & 0,61 & 0,83 & 0,56 & 0,71 & 0,70 \\
rata & & & & & & \\
\hline
\end{tabular}

\section{Tinggi Tanaman (cm)}

Hasil analisis ragam menunjukkan bahwa tidak terdapat interaksi antara pemberian jenis biochar dan dosis pupuk kandang sapi terhadap tinggi tanaman pakchoy. Pemberian jenis biochar tidak menunjukkan pengaruh terhadap tinggi tanaman. Pemberian dosis pupuk kandang sapi tidak menunjukkan pengaruh terhadap tinggi tanaman. Tinggi tanaman akibat perlakuan biochar dan pupuk kandang sapi disajikan pada Tabel 6. Ketika penyerapan unsur hara terhambat maka pembelahan sel akan terhambat. Pembalahan sel yang terhambat menyebabkan tinggi tanaman yang 
dihasilkan akan lebih pendek. Miguel et al., (2018) menyatakan unsur hara nitrogen dibutuhkan banyak untuk mendorong pertumbuhan batang tanaman. Jenis biochar dan dosis pupuk kandang sapi yang digunakan harus diperhatikan dari segi kualitas dan dosis yang dibutuhkan oleh tanaman untuk membantu dalam proses pertumbuhan vegetatif yang lebih optimal. $\mathrm{C} / \mathrm{N}$ rasio mempengaruhi ketersediaan nitrogen yang diserap oleh akar tanaman. Biochar dan pupuk kandang sapi

Tabel 6. Tinggi tanaman pakchoy akibat perlakuan pemberian jenis biochar dan pupuk kandang sapi

\begin{tabular}{|c|c|c|c|c|c|c|}
\hline \multirow{2}{*}{$\begin{array}{c}\text { Jenis } \\
\text { Biochar }\end{array}$} & \multicolumn{5}{|c|}{ Dosis Pupuk Kandang Sapi } & \multirow[t]{2}{*}{ Rata-rata } \\
\hline & $D_{1}$ & $D_{2}$ & $D_{3}$ & $\mathrm{D}_{4}$ & $D_{5}$ & \\
\hline$I_{1}$ & 21,13 & 21,13 & 20,67 & 19,40 & 19,17 & 19 \\
\hline $\mathrm{T}_{2}$ & 21, & & 17 & 19 & 19,67 & 07 \\
\hline Rata-rata & 21,38 & 21,38 & 19,25 & 19,47 & 19,42 & 19,99 \\
\hline
\end{tabular}

\section{Jumlah Daun (helai)}

Hasil analisis ragam menunjukkan bahwa tidak terdapat interaksi antara pemberian jenis biochar dan dosis pupuk kandang sapi terhadap jumlah daun tanaman pakchoy. Pemberian jenis biochar tidak menunjukkan pengaruh terhadap jumlah daun. Pemberian dosis pupuk kandang sapi tidak menunjukkan pengaruh terhadap jumlah daun. Jumlah daun akibat perlakuan biochar dan pupuk kandang sapi disajikan pada Tabel 7. Jumlah daun tanaman pakchoy dipengaruhi oleh ketersediaan nitrogen di dalam tanah. Nitrogen berperan penting dalam proses pertumbuhan daun. Pupuk kandang sapi dan biochar yang diberikan masih mengandung $\mathrm{C} / \mathrm{N}$ rasio yang cukup tinggi. Hal tersebut menunjukkan bahwa mikro organisme akan menggunakan nitrogen yang ada untuk proses metabolisme dalam tubuhnya, kejadian tersebut berdampak pada kurangnya nitrogen tersedia di dalam tanah sehingga pada saat pertumbuhan daun tanaman akan kekurangan unsur hara nitrogen. Hal ini sesuai pendapat Tegeder dan Daubresse (2018) yang menyatakan bahwa nitrogen merupakan suatu nutrisi dasar bagi pertumbuhan tanaman yang diperlukan dalam jumlah besar untuk memperoleh produksi yang maksimum.

Tabel 7. Jumlah daun tanaman pakchoy akibat perlakuan pemberian jenis biochar dan pupuk kandang sapi

\begin{tabular}{|c|c|c|c|c|c|c|}
\hline \multirow{2}{*}{$\begin{array}{c}\text { Jenis } \\
\text { Biochar }\end{array}$} & \multicolumn{5}{|c|}{ Dosis Pupuk Kandang Sapi } & \multirow{2}{*}{ Rata-rata } \\
\hline & $D_{1}$ & $\mathrm{D}_{2}$ & $D_{3}$ & $\mathrm{D}_{4}$ & $D_{5}$ & \\
\hline$T_{1}$ & 15,33 & 15,00 & 17,00 & 14,33 & 12,67 & 14,87 \\
\hline $\mathrm{T}_{2}$ & 14,3 & 13 & 15 , & 14 & 15,33 & 14,53 \\
\hline Rata-rata & 14,83 & 14,17 & 16,00 & 14,50 & 14,00 & 14,70 \\
\hline
\end{tabular}

\section{Berat Segar Tajuk (g)}

Hasil analisis ragam menunjukkan bahwa tidak terdapat interaksi antara pemberian jenis biochar dan dosis pupuk kandang sapi terhadap berat segar tajuk tanaman pakchoy. Pemberian jenis biochar tidak menunjukkan pengaruh terhadap berat segar tajuk. Pemberian dosis pupuk kandang sapi tidak menunjukkan pengaruh terhadap berat segar tajuk. Berat segar tajuk akibat perlakuan biochar dan pupuk kandang sapi disajikan pada Tabel 8. Pemberian jenis biochar, dosis pupuk kandang sapi, dan kombinasi kedua perlakuan tidak berpengaruh nyata terhadap berat segar tajuk disebabkan tidak berbeda nyatanya juga pertumbuhan vegetatif yaitu tinggi dan jumlah daun. Pakchoy merupakan tanaman mengandung banyak air sehingga semakin tinggi tanaman dan banyak jumlah daun maka akan banyak kandungan air dalam tanaman yang digunakan mengandung $\mathrm{C} / \mathrm{N}$ rasio yang masih tinggi sehingga lebih sukar untuk terdekomposisi sehingga penyerapan unsur hara oleh akar dari dalam tanah belum dapat memenuhi kebutuhan tanaman. Hal ini sesuai dengan pendapat Liu et al., (2014) yang menyatakan bahwa kandungan nitrogen yang berada di dalam pupuk organik bersifat slow release sehingga sulit diserap oleh akar sebagai elemen penting untuk pertumbuhan tanaman yang optimal.

dan secara otomatis berat segar tajuk semakin meningkat, begitu juga sebaliknya. Hal ini sesuai pendapat Subhan et al., (2016) yang menyatakan jika daya tumbuh vegetatif tanaman tinggi maka bobot segar tanaman akan tinggi juga.

Pertumbuhan tanaman dipacu oleh tersedianya unsur hara yang cukup dan mengakibatkan terjadinya peningkatan berat segar. Tinggi tanaman dan jumlah daun yang meningkat terjadi karena proses pembelahan, peningkatan, dan pembesaran sel sehingga berdampak pada peningkatan berat segar. Pupuk kandang sapi terkandung unsur hara yang lengkap namun belum dapat mencukupi kebutuhan pertumbuhan dan perkembangan tanaman pakchoy. Unsur hara khususnya nitrogen berperan penting dalam membantu proses fotosintesis sehingga akan meningkatkan berat basah tanaman. Hal ini sesuai pendapat Srie (2014) bahwa tersedianya dan terserapnya unsur hara yang optimal akan menghasilkan bobot segar tanaman yang meningkat.Pemberian biochar bukan merupakan pupuk namun bahan amelioran sehingga tidak memiliki unsur hara yang cukup untuk tanaman agar dapat diserap. Tidak tersedianya unsur hara tersebut membuat tanaman tidak mendapatkan nutrisi untuk memacu proses fotosintesis. Semakin banyak unsur hara yang diangkut melalui air dan tersimpan oleh tanaman maka proses fotosintesis akan semakin baik pula karena bahan utama fotosintesis telah terpenuhi. Penelitian Anjarwati et al., (2017) mengemukakan bahwa berlangsungnya proses fotosintesis dengan baik akan membuat penimbunan asimilat semakin baik pula sehingga berpengaruh terhadap peningkatan bobot segar tanaman.

Tabel 8. Berat segar tajuk tanaman pakchoy akibat perlakuan pemberian jenis biochar dan pupuk kandang sapi

\begin{tabular}{ccccccc}
\hline Jenis & \multicolumn{5}{c}{ Dosis Pupuk Kandang Sapi } & Rata-rata \\
\cline { 2 - 7 } Biochar & $\mathrm{D}_{1}$ & $\mathrm{D}_{2}$ & $\mathrm{D}_{3}$ & $\mathrm{D}_{4}$ & $\mathrm{D}_{5}$ & \\
\hline $\mathrm{T}_{1}$ & 51,60 & 43,81 & 42,64 & 45,15 & 38,64 & 44,37 \\
$\mathrm{~T}_{2}$ & 49,81 & 24,61 & 63,46 & 39,44 & 46,23 & 44,71 \\
Rata-rata & 50,70 & 34,21 & 53,05 & 42,30 & 42,44 & 44,54 \\
\hline
\end{tabular}

\section{KESIMPULAN}

Interaksi antara pemberian biochar tongkol jagung dan pupuk kandang sapi 25 ton/ha memberikan hasil terbaik terhadap peningkatkan daya simpan air pada tanah berpasir. Pemberian dosis pupuk kandang sapi berpengaruh terhadap berat volume dan porositas tanah sedangkan serapan nitrogen, tinggi tanaman, jumlah daun, dan berat segar tajuk tidak berpengaruh terhadap jenis biochar dan peningkatan dosis pupuk kandang sapi.

\section{DAFTAR PUSTAKA}

Anjarwati, H., S. Waluyo, \& S. Purwanti. (2017). Pengaruh macam media dan takaran pupuk kandang kambing terhadap pertumbuhan dan hasil sawi hijau (Brassica rapa L.). Vegetalika 6(1):35-45. 
Aslam, Z., M. Khalid, \& M. Aon. (2014). Impact of biochar on soil physical properties. Scholarly Journal of Agricultural Science 4(5):280-284.

Augustien, N. \& H. Suhardjono. (2017). Peranan berbagai komposisi media tanam organik terhadap tanaman sawi (Brassica juncea L.) di polybag. J IImuilmu Pertanian 1(1):54-58.

Binardi, S. (2014). Pengaruh pengolahan tanah dan pupuk organik bokhasi terhadap pertumbuhan dan hasil tanaman kedelai (Glycine max L.) kultivar wilis. J Istek 8(1):29-46.

Carvalho, M. L., M. T. D. Moraes, C. E. P. Cerri, \& M. R. Cherubin. (2020). Biochar amendmentenhances water retention in a tropical sandy soil. Agriculture 10(62):1-13.

Damayani, D., Nurlaeny, N., \& Kamil, S. E. (2014). Efek residu dari kombinasi media tanam abu vulkanik merapi, pupuk kandang sapi dan tanah mineral terhadap C-organik, kapasitas pegang air, dan bobot kering pupus tanaman jagung (Zea mays L.). Bionatura 15(3):196-202.

Dariah \& N. L. Nurida. (2012). Pemanfaatan biochar untuk meningkatkan produktivitas lahan kering beriklim kering. Buana Sains 12(2):33-38.

Direktorat Jendral Hortikultura. (2020). Statistika Produksi Hortikultura Tahun 2019. Badan Pusat Statistik dan Direktorat Jendral Hortikultura, Kementrian Pertanian.

Dokoohaki, H., F. E. Miguez, D. Laird, R. Horton, \& A. S. Basso. (2017). Assessing the biochar effects on selected physical properties of a sandy soil : an analytical approach. Communications in Soil Science and Plant Analysis 48(12):1387-1398 .

Hasibuan, I. (2017). Konservasi lahan marjinal dengan aplikasi biochar plus. J Agroqua 15(2):43-50.

Herath, H, M. S. K., M. C. Arbestain, \& M. Hedley. (2013). Effect of biochar on soil physical properties in two contrasting soils: an alfisol and an andisol. Geoderma 188-197.

Indoria, A. K., Ch. S. Rao, K. L. Sharma, \& K. S. Reddy. (2017). Conservation agriculture - a panacea to improve soil physical health. Current Science 112(1):52-61.

Kasih, G. C., Y. Yusran, \& Zulkaidhah. (2019). Kondisi fisik tanah di bawah tegakan pinus (Pinus merkusii Jungh. et de Vriese) dan padang rumput Desa Watutau Kecamatan Lore Poere Kabupaten Poso Sulawesi Tengah. J FlorestSains 16(2):60-68.

Liu, C. W., Y. Sung, B. C. Chen, \& H. Y. Lai. (2014). Effects of nitrogen fertilizers on the growth and nitrate content of lettuce (Lactuce sative L.). International Journal of Environmental Research and Public Health
11:4427-4440.

Marlina, N., R. I. S. Aminah, Rosmiah, \& L. R. Setel. (2015). Aplikasi pupuk kandang kotoran ayam pada tanaman kacang tanah (Arachis hypogeae L.). Biosaintifika 7(2):136-141.

Marzuki, Sufradi \& Manfarizah. (2012). Sifat fisika dan hasil kedelai (Glycine max $\mathrm{L}$ ) pada tanah terkompaksi akibat cacing tanah dan bahan organik. J Manajemen Sumberdaya Lahan 1(1)23-31.

Miguel, J., D. C. B. B. Gomes \& C. N. Nabais. (2018). The influence of dosing cattle manure and organic liquid fertilizers towards growth and crop yield of lettuce (Lactuca sativa L.) on three different soil types. International J. of Development Research 8(12):24604-24611.

Sholikhin, R., Nurbaiti \& M. A. Khoiri. 2014. Pemberian urin sapi terhadap pertumbuhan dan produksi tanaman sawi (Brassica juncea L.). JOM Faperta $1(2): 1-10$.

Srie, E. (2014). Pengaruh berbagai dosis dan cara apilkasi pupuk urea terhadap produksi tanaman sawi (Brassica juncea) pada tanah inceptisol marellan. $J$ Agroekoteknologi 2(2):770-778.

Subhan, O. D. Hajoeningtijas \& A. M. Purnawanto. (2016). Uji efisiensi budi daya tumpangsari tanaman kacang buncing (Phaseolusvulgaris L.) dengan sawi putih (Brassica juncea L.) pada pola tanam yang berbeda. Agritech 18(2):80-86.

Suharyani, F. Kusmiyati \& Karno. (2012). Pengaruh metode perbaikan tanah salin terhadap serapan nitrogen dan fosfor rumput benggala (Panicum maximum). Animal Agriculture J 1(2):168-176.

Tegeder, M. \& C. M. Daubresse. (2018). Source and sink mechanisms of nitrogen transport and use. New Phytologist 217:35-53.

Wibowo, W. A., B. Hariyono, \& Z. Kusuma. (2016). Pengaruh biochar, abu ketel dan pupuk kandang terhadap pencucian nitrogen tanah berpasir Asembagus, Situbondo. J Tanah dan Sumberdaya Lahan 3(1):269-278.

Yuan, C., S. Feng, J. Wang, Z. Huo \& Q. Ji. (2018). Effects of irrigation water salinity on soil salt content distribution, soil physical properties and water use efficiency of maize for sedd production in arid Nortwest China. Int Journal Agric and Bio Eng 11(3) :137-145.

Zupriadi, R., N. Chaniago, \& S. S. Ningsih. (2018). Pengaruh pemberian pupuk organik granula kotoran sapi dan pupuk organik cair terhadap pertumbuhan dan produksi tanaman sawi pakcoy (Brassica chinensis L.). Bernas Agricultural Research $J$ 14(1):107-118. 